e-Jurnal Ilmiah BIOSAINTROPIS (BIOSCIENCE-TROPIC)

Volume 6/ No.: 1 / Halaman 82 - 88 / Agustus Tahun 2020

ISSN : 2460-9455 (e) - 2338-2805(p)

\title{
Keanekaragaman Plankton pada Kolam Bioflok
}

\section{The Pankton Diversity in Bioflok Pond}

\author{
Yulan Hardias Putri ${ }^{1 *}$, Hari Santoso $^{2 * *}$, Ahmad Syauqi $^{3}$ \\ ${ }^{1}$ Jurusan Biologi Universitas Islam Malang, Indonesia
}

\begin{abstract}
ABSTRAK
Kesuburan perairan di kolam bioflok sangat tergantung pada keberadaan plankton yang merupakan organisme yang hidup melayang di kolam perairan dan berperan penting sebagai sumber pakan alami. Penelitian ini bertujuan untuk menganalisa kelimpahan dan keragaman plankton di kolam bioflok yang diberi probiotik. Penelitian ini menggunakan metode survei berupa pengamatan, pengukuran parameter air, pengambilan sampel plankton pada kolam bioflok yang sudah di beri perlakuan probiotik dengan dosis yang telah di tentukan oleh petani tambak pada kedalaman kolam bioflok $1 \mathrm{~m}$ dengan diameter $2 \mathrm{~m}$. Analisis statistik yang digunakan adalah uji-T untuk mengetahui perbedaan keanekaragaman plankton antara pagi, siang dan sore hari. Hasil penelitian mendapatkan fitoplankton sebanyak 10 kelas dan 26 genus fitoplankton, yaitu Kelas Cyanophyceae 6 genus meliputi Synechococcus, Oscilatoria, Choococcus, Spirulina, Microcystis, Scytonema. Kelas Chlorophyceae 6 genus yaitu Haematococcus, Chlorella, Stigeoclonium, Calodophora, Tetraedon, Pyrobotrys. Kelas Bacillariophyceae 5 genus yaitu Navicula, Eunotia, Cartuicula, Melosira, Rhaicosphera. Kelas Trebouxiophyceae 2 genus yaitu Botryococcus, Dictyosphaerium. Kelas Euglenoidea 1 genus yaitu Euglena. Kelas Cryptophyceae 1 genus yaitu Rhodomonas. Kelas Charophyceae 2 genus Mougeotia dan Cryptomonas. Kelas Zygnematophyceae terdapat genus Closterium. Kelas Cyanophyta terdapat genus Anacystis. Kelas Chrysophyceae terdapat genus Dinobryon. Dari hasil identifikasi ditemukan Zooplankton dengan 3 kelas dan 3 genus yaitu kelas Branchiopoda yaitu genus Holopedium. Kelas Maxillopoda yaitu genus Copepoda. Kelas Monogononta yaitu genus Ascomorpha. Hasil uji statistika menujukan keragaman plankton pada setiap ulangan berbeda nyata.
\end{abstract}

Kata Kunci: Plankton, Probiotik, Bioflok

\section{ABSTRACT}

Aquatic fertility in biofloc ponds is very dependent on the presence of plankton, an organism that lives floating in aquatic ponds and plays an important role as a source of natural food. This research aim to analyze the abundance and diversity of plankton in biofloc pools fed with probiotics. This study uses survey methods in the form of observations, measurement of water parameters, plankton sampling in biofloc ponds that have been given probiotic treatment at a dose that has been determined by the farmer at a depth of $1 \mathrm{~m}$ biofloc pool with a diameter of $2 \mathrm{~m}$. The statistical analyzed used is the T test to diversity differences in plankton abundance between morning, afternoon and evening. The results obtained as many as 10 genus of phytoplankton and 26 genus of phytoplankton, namely Class 6 Cyanophyceae genus including Synechococcus, Oscilatoria, Choococcus, Spirulina, Microcystis, Scytonema. Chlorophyceae class 6 genus namely Haematococcus, Chlorella, Stigeoclonium, Calodophora, Tetraedon, Pyrobotrys. Bacillariophyceae class 5 genus namely Navicula, Eunotia, Cartuicula, Melosira, Rhaicosphera. Class Trebouxiophyceae 2 genus namely Botryococcus, Dictyosphaerium. The genus Euglenoidea 1 is Euglena. Cryptophyceae class 1 genus is Rhodomonas. Class Charophyceae 2 genus Mougeotia and Cryptomonas. The Zygnematophyceae class contains the Closterium genus. The Cyanophyta class contains the Anacystis genus. The Chrysophyceae class contains Dinobryon genus. From the identification results found Zooplankton with 3 classes and 3 genus namely Branchiopoda class, namely the Holopedium genus. The Maxillopoda class is the Copepoda genus. The Monogononta class is the Ascomorpha genus. The statistical test results showed that the diversity in each test was significantly different.

Keywords: Plankton, Probiotics, Biofloc

\footnotetext{
*) Yulan Hardias Putri, Jurusan Biologi,FMIPA UNISMA,085604617807, e-mail: yulanhardias12@gmail.com,

$\left.{ }^{* *}\right)$ Drs.Hari Santoso,M.Biomed Jurusan Biologi FMIPA UNISMA, Jl. MT Haryono 193, Malang 65144, Telp.(0341)772115 and e-mail: harisantoso.m.biomed@gmail.com
}

Diterima Tanggal 22 Juli 2020 - Dipublikasikan Tanggal 25 Agustus 2020 
e-Jurnal Ilmiah BIOSAINTROPIS (BIOSCIENCE-TROPIC)

Volume 6/ No.: 1 / Halaman 82 - 88 / Agustus Tahun 2020

ISSN : 2460-9455 (e) - 2338-2805(p)

\section{Pendahuluan}

Probiotik merupakan alternatif dalam mengatasi masalah kualitas air dalam akuakultur yang diadaptasi dari teknik pengolahan limbah domestik secara konvensional [1]. Kesuburan perairan dapat mempengaruhi produktivitas hasil budidaya yang berupa pakan alami (plankton). Merurut Kuhn [2] dalam aplikasi teknologi probiotik, probiotik berperan dalam mengatasi kualitas air, peningkatan biosekuriti, peningkatan produktivitas, peningkatan efisiensi pakan dan penurunan biaya produksi melalui penurunan biaya pakan.

Plankton dalam kehidupan biota perairan sangat penting karena memiliki peran dan sebagai sumber pakan alami [3]. Keragaman plankton dapat menunjukkan tingkat kompleksitas dari struktur komunitas biota perairan. Keragaman plankton akan berkurang jika hanya didominasi oleh sejumlah kecil spesies. Adanya penurunan indeks diversitas dapat disebabkan karena terjadinya pencemaran dan eutrofikasi [4].

Ekologi perairan mengambarkan adanya plankton di dalam perairan yang berfungsi sebagai pakan alami [5]. Lingkungan perairan yang stabil dapat ditandai dengan keragaman plankton yang tinggi, jumlah individu dalam setiap spesies yang tinggi dan merata dan kualitas air yang sesuai untuk pertumbuhan organisme budidaya. Komunitas plankton sangat dipengaruhi berbagai faktor lingkungan baik yang bersifat fisika maupun kimia [6].

Plankton terbagi menjadi dua kelompok, yaitu: zooplankton dan fitoplankton [7]. Kelimpahan fitoplankton dapat digunakan sebagai bioindikator kualitas perairan, jika kelimpahan fitoplankton dalam perairan tinggi maka habitat tersebut dikatakan subur sehingga dapat memenuhi kebutuhan hidup organisme abiotik lainnya. Beberapa spesies plankton memiliki batasan toleransi terhadap zat-zat limbah organik atau kimia [8].

Fitoplankton mempunyai siklus hidup yang pendek, memiliki respon terhadap perubahan lingkungan yang sangat cepat dan sebagai produsen primer yang menghasilkan bahan organik serta oksigen melalui proses fotosintesis bagi kehidupan perairan. Proses fotosintesis pada fitoplankton akan memperluas distribusi fitoplankton secara horizontal, sehingga menjadi indikator untuk kualitas air [9]. Pada kondisi lingkungan dan ketersediaan fitoplankton berkurang bagi kebutuhan zooplankton menyebabkan zooplankton mencari tempat lain yang kondisinya sesuai, bahkan terjadi kematian [10].

Dari uraian diatas peneliti lakuakan penelitian untuk menganalisa keanekaragaman plankton di tambak yang diberi perlakuan probiotik dengan melihat jenis, keanekaragaman plankton.

\section{Material dan Metode}

\section{Bahan dan Alat}

Bahan yang digunakan dalam penelitian ini air sampel tambak budidaya ikan lele kecamatan. Dau, Kabupaten. Malang, larutan formalin

Alat yang digunakan sebagai berikut: Jaring plankton (Plankton net No. 25), kamera digital, $\mathrm{pH}$ meter, refractometer, botol sampel/ botol winkler, neubauer Improved, mikroskop, pipet, kertas label, buku identifikasi plankton [11], ATK

\section{Metode}

Jenis penelitian yang dilakukan adalah penelitian menggunakan metode survei berupa pengamatan, pengukuran parameter air, pengambilan sampel plankton pada kolam bioflok yang sudah di beri perlakuan probiotik dengan dosis yang telah di tentukan oleh petani tambak yang terletak di Kecamatan. Dau, Kabupaten. Malang dengan kedalaman tambak $1 \mathrm{~m}$ dengan diameter $2 \mathrm{~m}$. Penelitian ini menggunakan Rancangan Acak Lengkap (RAL) yang terdiri dari 5 ulangan dan 3 perlakuan dimana pada setiap perlakuan terdapat 3 titik (Permukaan, tengah, dasar) dan total jumlah sampel yang didapat yaitu 45 sampel.

\section{Cara Kerja}

Pengambilan Sampel: Pengambilan sampel dari 3 kolam yang sudah diberi perlakuan probiotik dilakukan secara acak, pengambilan secara acak ini dilakukan dengan cara menentukan dengan 
e-Jurnal Ilmiah BIOSAINTROPIS (BIOSCIENCE-TROPIC)

Volume 6/ No.: 1 / Halaman 82 - 88 / Agustus Tahun 2020

ISSN : 2460-9455 (e) - 2338-2805(p)

mengambil nomor urut undian untuk memilih kolam yang akan dilakukan untuk pengamatan pada hari ke 1-5 dan dilakukan analisis deskriptif, pengambilan sampel dilakukan selama 5 pengulangan dengan 3 perlakuan yaitu pagi hari pkl. 06.00 , siang hari pkl 12.00 dan sore hari pkl 17.00 dan setiap kolam diambil 3 titik pada bagian (dasar, tengah dan permukaan). Pengambilan sampel dilakukan dengan cara mengambil sampel menggunakan plankton net berukuran no. 25 mesh selanjutnya botol pengumpul dilepas lalu dipindahkan ke botol winkler $100 \mathrm{ml}$. Sampel dalam botol winkler $100 \mathrm{ml}$ diawetkan dengan 4 tetes formalin $4 \%$ dan 5 tetes terusi 3 ppm $\left(\mathrm{CuSO}_{4} 5 \mathrm{H}_{2} \mathrm{O}\right)$.

Pengukuran Kualitas Perairan: Pengukuran kualitas Air meliputi pH dan Salinitas yang masingmasing diukur dengan menggunakan $\mathrm{pH}$ meter dan refraktometer

Identifikasi Plankton: Identifikasi plankton dilakukan di laboratoriun Fakultas Matematika dan Ilmu Pengetahuan Alam Universitas Islam Malang menggunakan mikroskop digital optilab. Langkah pertama yang dilakukan yaitu dengan cara mengambil hasil fiksasi plankton dari botol winkler menggunakan pipet tetes dan di teteskan ke dalam Neubauer improved dan di tutup dengan gelas penutup dan diamati di mikroskop digital Optilab dan secara otomatis gambar akan muncul pada layer computer. Kemudian dilakukan identifikasi plankton dengan menggunakan buku pedoman [11].

Analisis Data: Data yang diperoleh dianalisa menggunakan statistic uji $\mathrm{T}$ untuk mengetahui perbedaan keanekaragaman plankton pada waktu pagi, siang, sore.

\section{Hasil dan Diskusi}

Dari penelitian yang telah dilakukan di lapangan serta dilakukan identifikasi menurut buku The Plankton of South Vietnam, Fresh Water and Marine Plankton [11]. Di peroleh Plankton sebagai berikut

Tabel.1 Spesies plankton yang ditemukan pada Kolam Bioflok yang diberi Probiotik

\begin{tabular}{lll}
\hline Kelompok & Kelas & Genus \\
\hline Fitoplankton & Cyanophyceae & Synechococcus \\
& & Oscilatoria \\
& & Choococcus \\
& Spirulina \\
& Microcystis \\
& Scytonema \\
& Haematococcus \\
& Chlorella \\
& Bacillariophyceae & Stigeoclonium \\
& Calodophora \\
& Tetraedon \\
& Pyrobotrys \\
& Navicula \\
& Eunotia \\
& Trebouxiophyceae & Cartuicula \\
& Melosira \\
& Euglenoidea & Rhaicosphera \\
& Cryptophyceae & Botryococcus \\
& Dictyosphaerium \\
& Charophyceae & Euglena \\
Zygnematophyceae & Rhodomonas \\
Cyanophyta & Cryptomonas \\
Chrysophyceae & Mougeotia \\
Branchiopoda & Closterium \\
Maxillopoda & Anacystis \\
Monogononta & Dinobryon \\
& & Holopedium \\
& Copepod \\
& Ascomorpha \\
\hline
\end{tabular}

Jumlah genus dan keanekaragaman jenis Plankton sangat berbeda dimana zooplankton yang ditemukan pada kolam bioflok memiliki jumlah yang lebih sedikit dibandingkan Fitoplankton, jumlah genus pada Zooplankton terdapat 3 kelas dan 3 genus dan jenis fitoplankton ditemukan 9 kelas dan 28 genus (Tabel 1). Pernyataan ini sesuai dengan pernyataan [12] jika jumlah zooplankton yang 
e-Jurnal Ilmiah BIOSAINTROPIS (BIOSCIENCE-TROPIC)

Volume 6/ No.: 1 / Halaman 82 - 88 / Agustus Tahun 2020

ISSN : 2460-9455 (e) - 2338-2805(p)

mempunyai jumlah yang lebih rendah dibandingkan fitoplankton yang ditemukan merupakan kondisi alami sebagai organisme yang menduduki trofik level yang lebih tinggi dibandingkan dengan fitoplankton. Selain itu ada faktor- faktor lain yang mengakibatkan rendahnya populasi zooplankton (Tabel 1) di kolam bioflok yaitu karena adanya organisme lele yang merupakan organisme omnivore yang memanfaatkan zooplankton sebagai sumber makanan alaminya. Hal tersebut sesuai dengan pernyataan [13], bahwa tinggi rendahnya kepadatan zooplankton pada suatu perairan tidak hanya ditentukan oleh faktor unsur hara fosfat dan nitrat saja, akan tetapi faktor lingkungan lainnya serta predator juga sangat berpengaruh terhadap keberadaan zooplankton di dalam kolam bioflok. Jika kondisi lingkungan perairan terganggu maka hanya akan ada Zooplankton satu atau beberapa genus saja yang mampu bertahan dan berkembang lebih baik untuk menggantikan genus zooplankton lainnya yang tidak mampu untuk bertahan.

Pada penelitian [14] yang berjudul Keragaman Plankton dan Kondisi Perairan Tambak Intensif dan Tradisional Di Probolinggo Jawa Timur tanpa menggunakan probiotik didapatkan plankton pada tambak intensif 23 spesies dengan 16 spesies fitoplankton dan 7 spesies zooplankton dan untuk tambak tradisinal terdapat 10 spesies fitoplankton dan 3 spesies zooplankton, sedangkan pada penelitian ini dengan menggunakan probiotik di dapatkan Zooplankton 5 spesies dan fitoplankton ditemukan 28 spesies spesies. Pemberian probiotik berpengaruh terhadap jumlah plankton karena probiotik mengandung bakteri asam laktat yaitu Lactobacillus sp. Menurut [15], asam laktat dapat menghasilkan $\mathrm{pH}$ yang rendah pada substrat sehingga menimbulkan suasana asam, hal ini dapat mempengaruhi keankeragaman plankton pada suatu perairan.

Tabel 2. Hasil Analisis Statistika Uji t Pengamatan Plankton pada Waktu yang Berbeda

\begin{tabular}{cccc} 
Perbandingan & db & t Hitung & t Tabel \\
\hline A dan B & 6 & 50,80 & $2,447^{*}$ \\
A dan C & 6 & 186,07 & $12,71^{*}$ \\
B dan C & 16 & 2,389 & $2,120^{*}$ \\
\hline
\end{tabular}

Keterangan:

A: Waktu Pagi Hari

B: Waktu Siang Hari

C: Waktu Sore Hari

*: Berbeda Nyata

Untuk melihat perbedaan antara perubahan zooplankton pada waktu pagi, siang, sore dilakukan dengan uji $\mathrm{t}$ (Tabel 2). Dari hasil analisis uji t terdapat perbedaan zooplankton pada waktu pagi, siang, sore pada perbadingan A dan B t hitung 50,80 dengan $\mathrm{t}$ Tabel 2,447, pada perbandingan A dan $\mathrm{C} \mathrm{t}$ hitung 186,07 dengan t Tabel 12,71 dan perbandingan $\mathrm{B}$ dan $\mathrm{C} t$ hitung 2,389 dengan $\mathrm{t}$ Tabel 2,120 dari hasil analisis statistika menggunakan uji t dapat disimpulkan berbeda nyata bahwa keragaman di tempat A berbeda dengan $\mathrm{B}$, tempat $\mathrm{A}$ berbeda dengan $\mathrm{C}$ dan tempat $\mathrm{C}$ berbeda.

Adanya perbedaan dari uji t pada waktu yang berbeda ini disebabkan pada jenis fitoplankton, dimana pada pagi hari intensitas cahaya matahari sangat optimal untuk melakukan proses fotosintesis sehingga terdapat banyak unsur-unsur hara yang terdapat pada stasiun tersebut, sedangkan pada waktu sore hari intensitas cahaya matahari menurun. Pada waktu pagi hari fitoplankton melakukan migrasi vertikal dengan tujuan untuk memperoleh sinar matahari yang optimal untuk pertumbuhan selnya dan zooplankton akan mengikuti pergerakan fitoplankton, karena fitoplankton sendiri sebagai pakan alami bagi Zooplankton [16].

Hasil pengukuran parameter kuallitas air pada kolam lele yang Sudah diberi Perlakuan Probiotik yaitu salinitas, $\mathrm{pH}$. Pengukuran $\mathrm{pH}$ air bertujuan untuk mengetahui tingkat keasaman air tambak karena dapat berpengaruh terhadap nafsu makan, serta pertumbuhan lele. $\mathrm{pH}$ yang buruk dapat menyebabkan plankton buruk dan mati. $\mathrm{pH}$ merupakan salah satu parameter penting dalam suatu perairan karena dapat mengontrol tipe dan laju kecepatan reaksi beberapa bahan dalam air. Berdasarkan Penelitian yang telah di lakukan di dapatkan hasil grafik Derajat keasaman $(\mathrm{pH})$ sebagai berikut, Gambar 1. 
e-Jurnal Ilmiah BIOSAINTROPIS (BIOSCIENCE-TROPIC)

Volume 6/ No.: 1 / Halaman 82 - 88 / Agustus Tahun 2020

ISSN : 2460-9455 (e) - 2338-2805(p)

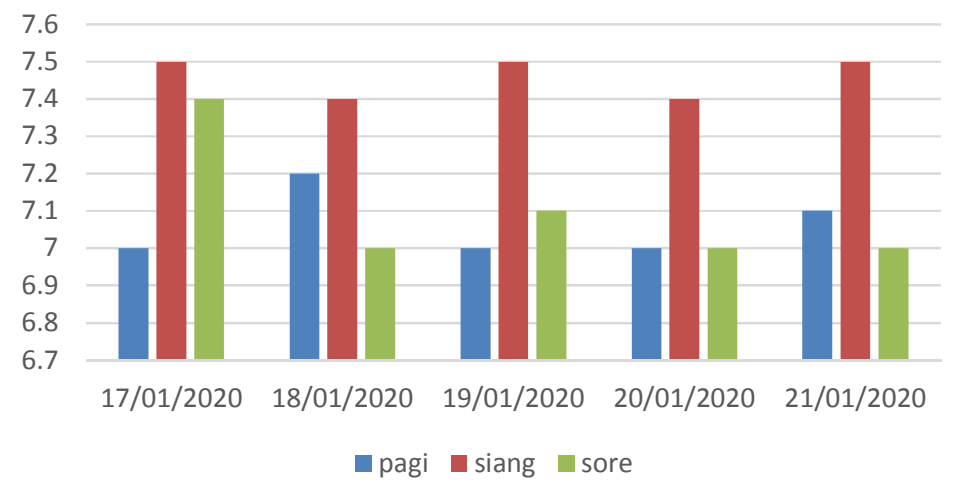

Gambar 1. Grafik Nilai Derajat Keasaman (pH) Selama Pengamatan

Dari hasil pengukuran $\mathrm{pH}$ dengan menggunakan $\mathrm{pH}$ meter didapatkan rata-rata $\mathrm{ph} 7-7,5$. Fluktasi nilai $\mathrm{pH}$ mengikuti aktivitas fotosintesis dan respirasi, pada umumnya $\mathrm{pH}$ air kolam bioflok pada umumnya pada waktu siang hari lebih tinggi dari pada pagi hari hal ini di karenakan karena adanya kegiatan fotosintesis fitoplankton yang menyerap $\mathrm{CO}_{2}$ sebaliknya pada pagi hari $\mathrm{CO}_{2}$ melimpah sebagai hasil dari pernapasan udang [17].

Organisme biotik dapat hidup dalam perairan yang memiliki nilai $\mathrm{pH}$ yang netral dengan kisaran antara asam lemah sampai basa lemah. Nilai $\mathrm{pH}$ yang sangat rendah akan membuat terjadinya gangguan metabolisme dan respirasi pada hewan abiotik. Disamping itu $\mathrm{pH}$ yang sangat rendah akan membuat mobilitas berbagai senyawa logam yang bersifat toksik semakin tinggi yang akan mengancam kelangsungan hidup organisme abiotik $\mathrm{pH}$ yang tinggi akan menyebabkan dan mempengaruhi keseimbangan antara ammonium dan ammoniak dalam air akan tergangu, dimana kenaikan $\mathrm{pH}$ di atas netral akan meningkatkan konsentrasi amoniak yang juga bersifat sangat toksik bagi organisme [18].

Nilai pengukuran $\mathrm{pH}$ dengan kisaran antara $7-8$ pada kolam bioflok ini sesuai dengan pendapat [19], yang menyatakan bahwa kisaran $\mathrm{pH}$ untuk budidaya adalah $7-9 . \mathrm{pH}$ yang dibutuhkan plankton adalah $7-8,5$. Pada $\mathrm{pH}$ yang rendah pertumbuhan plankton akan terhambat dan $\mathrm{pH}$ tinggi pada kolam bioflok akan membuat plankton akan bersifat fototaksis.

Menurut [20] derajat keasaman $(\mathrm{pH})$ air 7,5 - 8,5 ternyata sangat baik untuk budidaya ikan lele, sedangkan bila $\mathrm{pH}$ lebih dari 9,5 tidak akan berproduksi lagi.

Salinitas merupakan variable lingkungan yang mempengaruhi tingkat kenyamanan biota yang akan dibudidayakan selain dipergunakan untuk kelangsungan hidup dan pertumbuhannya [21]. Berdasarkan Penelitian yang telah di lakukan di dapatkan hasil grafik salinitas sebagai berikut, Gambar 2.

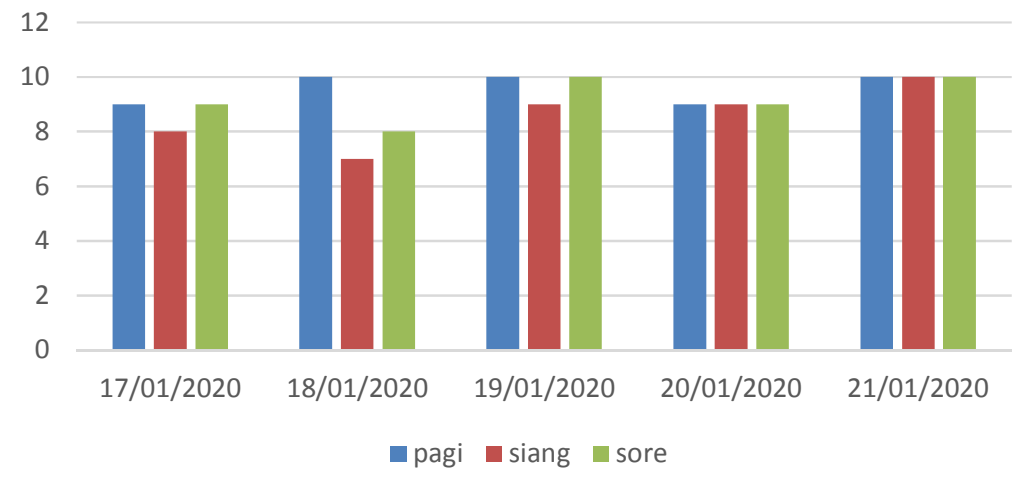

Gambar 2. Grafik Nilai Salinitas Selama Pengamatan 
e-Jurnal Ilmiah BIOSAINTROPIS (BIOSCIENCE-TROPIC)

Volume 6/ No.: 1 / Halaman 82 - 88 / Agustus Tahun 2020

ISSN : 2460-9455 (e) - 2338-2805(p)

Dari hasil pengukuran salinitas dengan menggunakan refraktometer setiap pagi, siang dan sore di dapatkan hasil rata-rata selama pengamatan yaitu 7-10 ppt. Salinitas merupakan komposisi ion-ion dalam perairan [22]. Dalam perairan terdapat enam elemen Ion-ion yang terdiri dari klorin, sodium, sulfur, magnesium, kalsium dan potassium. Kadar garam atau biasa disebut salinitas merupakan material yang terlarut dalam air. Salinitas sendiri dapat berfluktuasi karena adanya pengaruh penguapan dan hujan. Salinitas sendiri dapat mempengaruhi oleh pertumbuhan dan perkembangbiakan pada zooplankton, salinitas yang tidak sesuai dalam perairan dapat berpengaruh pada kelangsungan hidup dan pada tingkat pertumbuhan plankton, selain itu salinitas yang ekstrim dapat menghambat proses pertumbuhan dan meningkatkan kematian pada zooplankton [23]. Menurut [25], salinitas yang optimal untuk pertumbuhan plankton pada ait tawar yaitu 0-10 ppt, pada air payau 10-20 dan salinitas diatas 20 ppt untuk pertumbuhan plankton pada air laut.

Dari hasil pengukuran menunjukan salinitas yang cukup baik sesuai dengan pernyataan [24] pada salinitas 0-10 ppt salinitas yang optimal untuk pertumbuhan plankton. Adanya faktor biotik dan abiotik yang mempengerahui pertumbuhan plankton pada suatu perairan dimana faktor biotik yang berpengaruh pada salinitas di antaranya adalah produsen, yang merupakan sumber makanan bagi plankton dan adanya interaksi spesies serta pola siklus hidup pada setiap spesies dalam komunitas. Adapun faktor abiotik ialah fisika kimia air yang di antaranya suhu, kecepatan arus, kecerahan, $\mathrm{pH}$, Dissolved Oxygen (DO), karbondioksida (CO2), dan Biological Oxygen Demand (BOD) [25]. Kualitas air yang baik dapat mendukung plankton untuk bertahan hidup, dapat dilihat dari kemelimpahan dan keanekaragaman plankton, Probiotik sangat baik untuk mrmperbaiki kualitas air sehingga pada penelitian ini kualitas air sesuai untuk pertumbuhan ikan dan plankton.

\section{Kesimpulan}

Ditemukan 10 kelas dan 26 genus fitoplankton yaitu kelas Cyanophyceae dengan 6 genus Synechococcus, Oscilatoria, Choococcus, Spirulina, Microcystis, Scytonema. Kelas Chlorophyceae dengan 6 genus Haematococcus, Chlorella, Stigeoclonium, Calodophora, Tetraedon, Pyrobotrys. Kelas Bacillariophyceae dengan 5 genus, Navicula, Eunotia, Cartuicula, Melosira, Rhaicosphera. Kelas Trebouxiophyceae dengan 2 genus Botryococcus dan Dictyosphaerium. Kelas Euglenoidea dengan genus Euglena. Kelas Cryptophyceae dengan 3 genus Rhodomonas. Kelas Charophyceae dengan genus Mougeotia dan Cryptomonas. Kelas Zygnematophyceae dengan genus Closterium. Kelas Cyanophyta dengan genus Anacystis dan Kelas Chrysophyceae dengan genus Dinobryon untuk Zooplankton dengan 3 kelas dan 3 spesies yaitu kelas Branchiopoda dengan genus Holopedium. Kelas Maxillopoda dengan genus Copepod dan kelas Monogononta dengan genus Ascomorpha. Hasil uji statistika menunjukan perbedaan nyata pada keanekaragaman setiap genus.

\section{Daftar Pustaka}

[1] Avnimelech, Y. 2009. Biofloc Technology. A Pratical Guide Book. World Aquacultur Society. Technion Israel Institute of Technology

[2] Kuhn, DD, Boardman GD, Lawrence AL, Marsh L, \& Flick Jr. GJ. 2009. Microbial $\mathrm{fl}^{\circ} \mathrm{C}$ meal as a replacement ingredient for fish meal and soybean protein in shrimp feed. Aquaculture 296, 51-57.

[3] Nontji, A. 2008. Plankton Laut. LIPI Press. Jakarta

[4] Soedarti, T., Aristiana, J., dan Soegianto, A. 2006, Diversitas Fitoplankton Pada Ekosistem Perairan Waduk Sutami, Malang, Berk. Penel. Hayati, Vol. 11:97 - 103.

[5] Amin, M. dan Hendrajat, E.A., 2015. Pertumbuhan plankton Amin, M. dan Hendrajat, E.A., 2015. Pertumbuhan plankton pada tambak polikultur udang vaname (Litopenaeus vannamei) dan rumput laut Gracilaria verrucosa. Prosiding Simposium Nasional Kelautan dan Perikanan II. Fakultas Ilmu Klelautan dan Perikanan Universitas Hasanuddin, pp.181-187 
e-Jurnal Ilmiah BIOSAINTROPIS (BIOSCIENCE-TROPIC)

Volume 6/ No.: 1 / Halaman 82 - 88 / Agustus Tahun 2020

ISSN : 2460-9455 (e) - 2338-2805(p)

[6] Pirzan, A.M. dan P. R. Pong-Masak. 2007. Hubungan produktivitas tambak dengan keragaman fitoplankton di Sulawesi Selatan. Jurnal Riset Akuakultur. Badan Riset Kelautan dan Perikanan, Pusat Riset Perikanan Budidaya, Vol. 2(2):211-220.

[7] Sediadi. A. \& L.F. Wenno, 1995. Tingkat kesuburan dan kondisi hidrologi perairan mangrove Teluk Bintuni, Irian Jaya. Pros. Seminar V Ekosistem Mangrove.: 179-189.

[8] Maresi, S. R., Priyanti, dan Yunita, E. 2015. Fitoplankton Sebagai Bioindikator Saprobitas Perairan di Situ Bulakan Kota Tangerang. Jurnal Biologi, 8 (2).113-122.

[9] Anggraini, A., Sudarsono \& Sukiya, 2016. Kelimpahan dan Tingkat Kesuburan Plankton di Perairan Sungai Bedog. Jurnal Biologi, 5(6), pp. 1-10.

[10] Ruga, L, M. Langoya, A. Papua, dan B. Kolondama. 2014. Identifikasi Zooplankton di Perairan Pulau Bunaken Manado. Jurnal MIPA Unsrat Online Vol. 3 (2): 84 - 86.

[11] Shirota, A. 1966. The plankton of South Viet-Nam: Freshwater and Marine plankton. Over.Tech.Coop. Agen. Japan.

[12] Odum, H.T. 1971. Fundamental of Ecology $3^{\text {td }}$ Edition W.B. Sounders Company London: New York.

[13] Hidayat, M. 2013. Keanekaragaman plankton di Waduk Keuliling Kecamatan Kuta Cot Glie Kabupaten Aceh Besar. Jurnal Biotik. 1(2): 67-136, Edisi September 2013.

[14] Utojo. 2015. Keragaman Plankton dan Kondisi Perairan Tambak Intensif dan Tradisional di Probolingo Jawa Timur. Balai Penelitian dan Pengembangan Budidaya Air Payau. Sulawesi Selatan

[15] Buckle, K. A. et al, 1978. Ilmu Pangan. Penerbit UI PRESS. Jakarta.

[16] Nybakken, J. W. 1988. Biologi Laut Suatu Pendekatan Ekologis, PT. Gramedia, Jakarta.

[17] Haliman, R.W. dan D. Adijaya. 2005. Udang vannamei, Pembudidayaan dan Prospek Pasar Udang Putih yang Tahan Penyakit. Penebar Swadaya. Jakarta.

[18] Barus, T. A. (2004). Buku Pengantar Limnologi Studi Tentang Ekosistem Air Daratan. USU. Medan.

[19] Ekawati. 2003.Pengaruh Penggunaan Probiotik Biocin Dalam Pakan Buatan Terhadap Tingkat Kelulushidupan dan Pertumbuhan Ikan Patin (Pangasius sp). Skripsi. Program Studi Manajemen Sumber Daya Perikanan. Fakultas Perikanan. Universitas Brawijaya. Malang. 44 hal.

[20] Arifin Z. 2006. Budidaya Lele. Effhar. Semarang.

[21] Barus, T. A. 2001, Buku Limnologi. Universitas Sumatra Utara: Medan.

[22] Wetzel, R.G. 1983. Limnology. Saunder Company. Philadelphia

[23] Odum, H.T. 1993. Dasar-Dasar Ekologi. (Terjemahan Tjahjono Samingan).Edisi Ketiga. Universitas Gadjah Mada. Yogyakarta

[24] Sachlan, M. 1982. Planktonologi. Semarang: Fakultas Peternakan dan Perikanan Universitas Diponegoro.

[25] Hakim A. R., Dkk., 2011. Pengaruh Perbandingan Air Pengekstrak, Suhu Prespitasi, Dan Konsentrasi Kalium Klorida (KCL) Terhadap Mutu Karaginan. Jurnal Pasca Panen dan Bioteknologi Kelautan dan Perikanan Vol. 6 No.1 Edisi Juni 2011. 